Jika pembelajaran dilakukan dengan sungguh-sungguh oleh seorang pengajar dengan berbagai metode dan strategi pembelajaran yang aktif, kreatif, inovatif, dan menyenangkan, maka akan diperoleh dua hal sekaligus, yaitu tercapainya tujuan pembelajaran keterampilan membaca Arab dengan baik, dan juga penanaman nilai-nilai karakter pada jiwa peserta didik dengan baik tanpa adanya paksaan. Hal itu bermuara pada pendidikan nilai karakter yang tidak cukup berhenti pada ranah kognitif, tetapi ia sampai pada penghayatan dalam kehidupan. Dengan adanya integrasi pendidikan karakter tersebut, diharapkan pembelajaran membaca Arab dapat mencetak generasi bangsa yang mempunyai kedalaman spiritual, keagungan akhlak, keluasan ilmu, dan kematangan profesional. 


\section{DAFTAR PUSTAKA}

Abidin, Yunus. 2015. Pembelajaran Bahasa Berbasis Pendidikan Karakter, Bandung: PT. Refika Aditama.

Adisusilo, Sutarjo. 2013. Pembelajaran Nilai-Nilai Karakter (Konstruktivisme dan VCT Sebagai Inovasi Pendekatan Pembelajaran Afektif), Jakarta: Raja Grafindo Persada.

Depdiknas. 2010. Undang-Undang Sistem Pendidikan Nasional, Jakarta: Depdiknas. Hafid, Anwar, dkk. 2013. Konsep Dasar Ilmu Pendidikan, Bandung: Alfabeta.

Hermawan, Acep. 2014. Metodologi Pembelajaran Bahasa Arab, Bandung: PT. Remaja Rosdakarya Offset.

Izzan, Ahmad. 2007. Metodologi Pembelajaran Bahasa Arab, Bandung: Humaniora.

Mustofa, Syaiful. 2011. Strategi Pembelajaran Bahasa Arab Inovatif. Malang: UIN Maliki Press.

Saleh, Muwafik. 2012. Membangun Karakter dengan Hati Nurani (Pendidikan Karakter Sebagai Generasi Bangsa), Jakarta: Erlangga.

Said, Alamsyah, dan Andi Budiman. 2015.95 Strategi Mengajar Multiple Intelligences, Mengajar Sesuai Kerja Otak dan Gaya, Jakarta: Kencana. 


\title{
SEKSISME BAHASA ARAB DAN \\ TANTANGAN PEMBELAJARAN BAHASA ARAB
}

\author{
Inayatur Rosyidah \\ Program Khusus Perkuliahan Bahasa Arab \\ Universitas Islam Negeri Maulana Malik Ibrahim Malang \\ Email: alessandrorofik@yahoo.com
}

\begin{abstract}
Abstrak
Arabic sexism can be seen from the Arabic grammar system it self supporting the formation of sexist language. Arabic sexism in education, especially religious education in the form of subject matter and the education process increasingly dwarf women from the inequality of the patriarchal system. To build a world of equitable education without gender inequality originating from language sexism is to create gender-friendly language, restructure the curriculum, and require a paradigmatic, egalitarian, flexible, and persuasive learning step from all parties, especially teachers as the spearhead of the learning process.
\end{abstract}

Kata Kunci: Seksisme Bahasa Arab, Pembelajaran Bahasa Arab dan Al-Qur'an

\section{A. Pendahuluan}

Realitas universal menunjukkan adanya ketidakseimbangan penggunaan bahasa dalam menunjukan peran antara maskulin dan feminim. Sebagai contoh, dalam bahasa Indonesia, sufiks wati pada kata wartawati dan karyawati, misalnya, adalah tanda bahasa yang tertutup untuk menunjuk kepada perempuan. Kata tersebut diturunkan dari wartawan dan karyawan, yang bersifat lebih terbuka, mencakup laki-laki dan perempuan.

Dengan kata lain, bahasa merekam asumsi-asumsi yang diyakini oleh masyarakat mengenai bagaimana seharusnya seorang laki-laki atau perempuan berperilaku. Pembedaan seperti ini, sering dinamakan sebagai seksisme yang berujung pada maskulinitas dan feminitas dalam bahasa.

Bahasa Arab merupakan salah satu rumpun bahasa Semit tertua dan tetap eksis hingga sekarang. Sebagai bahasa agama yang tertuang dalam al-Qur'an dan hadis, menjadikan bahasa Arab begitu istimewa dibandingkan dengan bahasa yang lain. Bahasa Arab sebagai kalām Allah ternyata mengandung seksisme yang berpengaruh pada proses tekstualisasi al-Qur'an.

Dalam konteks ini, Syafiq Hasyim menyatakan sebagai berikut (Burhanuddin dan Fathurahman, 2004: 138): 
“. . . kita menyadari bahwa salah satu ciri bahasa Arab adalah wataknya yang seksis. Sedangkan Tuhan menggunakan bahasa Arab. Akibatnya seksisme bahasa tidak bisa terhindarkan masuk ke dalam al-Qur'an yang pada gilirannya masuk ke dalam disiplin ilmu-ilmu tradisional Islam ..."

Bahasa Arab menjadi salah satu bahasa asing yang dipelajari di Indonesia, dimulai dari pendidikan usia dini hingga perguruan tinggi. Bahasa Arab diajarkan bersama dengan berbagai disiplin ilmu lain seperti studi Islam, kutub turāts, dirāsah al-nushūs, studi fiqih, dan lain sebagainya.

Tulisan ini akan mengupas kecenderungan seksisme dalam bahasa Arab, sebagai bahasa yang memiliki perbedaan gender maskulin dan feminim berikut tantangan dalam pembelajarannya.

\section{B. Konsep Seksisme}

Menurut Shan Wareing, seksisme adalah bahasa yang merepresentasikan pria dan wanita secara tidak setara di mana anggota dari kelompok seks yang satu dianggap lebih rendah kemanusiaannya, lebih sederhana, lebih sedikit hak-haknya daripada anggota dari kelompok seks yang lain. Bahasa seksis biasanya menyajikan stereotip-stereotip tentang pria dan wanita yang kadang merugikan keduanya tapi lebih sering merugikan kaum wanita (Thomas dan Wareing, $2007: 106)$.

\section{Seksisme dalam Bahasa Arab}

Bahasa Arab sebagai kalām Allah ternyata mengandung seksisme yang berpengaruh pada proses tekstualisasi al-Qur'an. Bias tersebut tercermin dari tambahan (ziyādah) tā' marbüthah pada kata muslimah dan mu'minah misalnya, adalah tanda bahasa untuk menunjuk kepada perempuan. Kata tersebut diturunkan dari muslim dan mu'min. Atau dengan kata lain, perempuan diciptakan dari laki-laki dan untuk mendampingi laki-laki.

Selain itu, relasi gender dalam al-Qur'an terlihat dalam penggunaan dhamir (kata ganti) yang ditunjukkan untuk laki-laki dan perempuan. Sebagaimana yang digunakan dalam identitas gender, kata ganti laki-laki lebih mendominasi dalam al-Qur'an daripada kata ganti perempuan karena kaidah umum tata bahasa Arab menyatakan (Hazm, tanpa tahun: 324):

“Apabila khitābsuatunash digunakan dalam bentuk mudzakar, maka mu'annats 
termasuk di dalamnya selama tidak ada dalil yang mengecualikannya".

Sebagai kalām Allah yang berbahasa Arab, al-Qur'an juga mengikuti aturan ini, sebagaimana berikut:

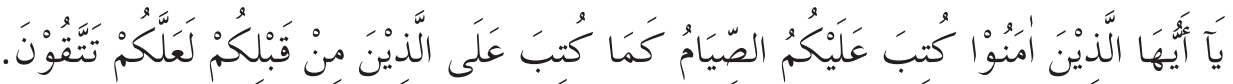

"Wahai orang-orang yang beriman, diwajibkan atas kamu berpuasa sebagaimana diwajibkan atas orang-orang sebelum kamu agar kamu bertakwa”. (QS. Al-Baqarah [2]: 183)

Maskulinitas ayat tersebut terletak pada kata yang dicetak miring. Dalam ayat tersebut khitāb laki-laki mencakup juga perempuan, jika tidak maka ayat di atas tidak dapat dijadikan landasan kewajiban berpuasa bagi perempuan.

Namun hal ini tidak berlaku untuk sebaliknya, yakni jika khitāb untuk perempuan, maka ia dikhususkan pada perempuan saja, seperti ayat berikut:

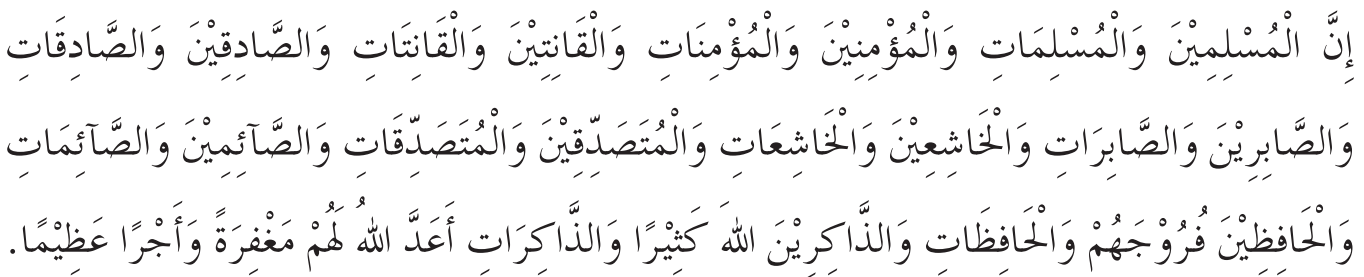

"Sungguh, laki-laki dan perempuan muslim, laki-laki dan perempuan mukmin, laki-laki dan perempuan yang tetap dalam ketaatannya, laki-laki dan perempuan yang benar, laki-laki dan perempuan yang sabar, laki-laki dan perempuan yang khusyuk, laki-laki dan perempuan yang bersedekah, laki-laki dan perempuan yang berpuasa, laki-laki dan perempuan yang memelihara kehormatannya, laki-laki dan perempuan yang banyak menyebut (nama) Allah, Allah telah menyediakan untuk mereka ampunan dan pahala yang besar". (QS. Al-Ahzāb [33]: 35)

\section{Seksisme Bahasa Arab Tinjauan Semantik}

Berikut pemaparan mengenai bentuk seksisme dalam bahasa Arab ditinjau dari segi semantik:

\section{Istilah yang menunjuk kepada laki-laki dan perempuan}

Kata laki-laki (رَجُج) dan kata perempuan (نََّاء)

Kata رَجَال dang jalam berbagai bentuknya terulang 55 kali dalam al-Qur'an. Dalam penelítian Nasarudin Umar, kata tersebut dapat mengandung beberapa makna, di antaranya adalah (Umar, 2001:147-159). 
Pertama, berarti gender laki-laki sebagaimana ayat berikut:

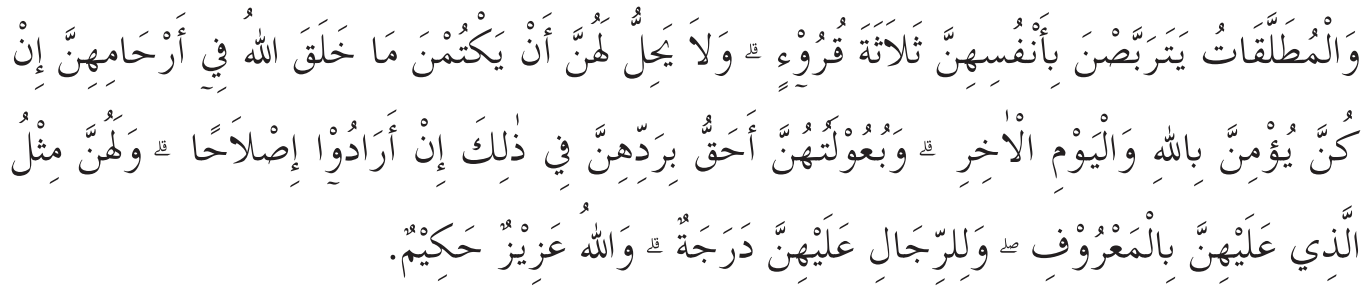

"Dan para istri yang diceraikan (wajib) menahan diri mereka (menunggu) tiga kali qurū' (jamak dari qar'u yang berarti suci atau haid). Tidak boleh bagi mereka menyembunyikan apa yang diciptakan Allah dalam Rahim mereka, jika mereka beriman kepada Allah dan hari akhir. Dan para suami mereka lebih berhak kembali kepada mereka dalam (masa) itu jika mereka menghendaki perbaikan. Dan mereka (para perempuan) mempunyai hak seimbang dengan kewajibannya menurut cara yang patut. Tetapi para suami mempunyai kelebihan di atas mereka (karena suami antara lain bertanggung jawab terhadap keselamatan dan kesejahteraan rumah tangga). Allah Mahaperkasa, Mahabijaksana”. (QS. Al-Baqarah [2]: 228)

Kedua, kata رَجُ secara umum mengandung arti laki-laki maupun perempuan sebagaimana ayat berikut:

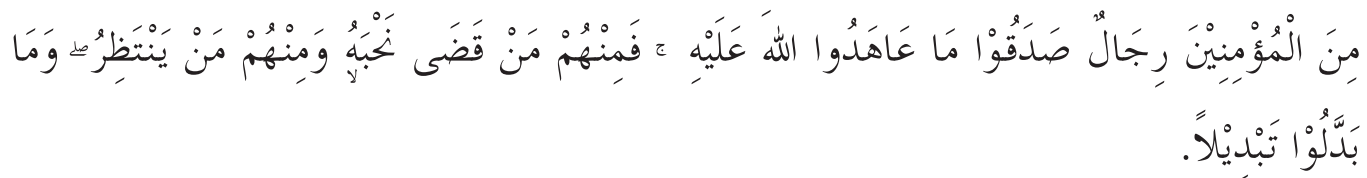

"Di antara orang-orang mukmin itu ada orang-orang yang menepati apa yang telah mereka janjikan kepada Allah. Dan di antara mereka ada yang gugur, dan di antara mereka ada (pula) yang menunggu- nunggu (menunggu apa yang telah Allah janjikan kepadanya) dan mereka sedikit pun tidak mengubah (janjinya)". (QS. Al-Ahzāb [33]: 23)

Ketiga, kata رَجُج berarti tokoh masyarakat sebagaimana ayat berikut:

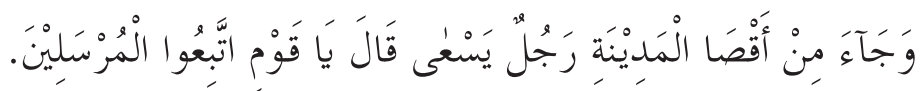

"Dan datanglah dari ujung kota, seorang laki-laki (menurut mufasir, lakilaki tersebut bernama Habib An-Najjar) dengan bergegas dia berkata, "Wahai kaumku, ikutilah utusan-utusan itu". (QS. Yāsīn [36]: 20)

Sementara kata نسَاء dalam berbagai bentuknya terulang 59 kali dalam alQur'an. Kata tersebut dapat mengandung beberapa makna, di antaranya adalah (Umar, 2001:160-164):

Pertama, berarti gender perempuan sebagaimana ayat berikut: 


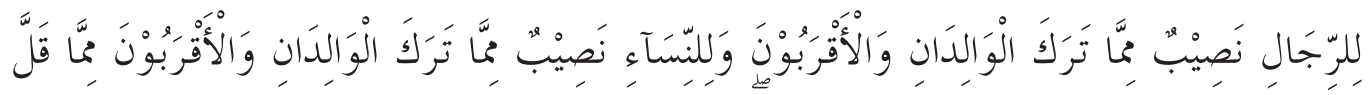

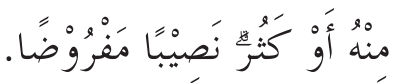

"Bagi laki-laki ada hak bagian dari harta peninggalan kedua orang tua dan kerabatnya, dan bagi perempuan ada hak bagian (pula) dari harta peninggalan kedua orang tua dan kerabatnya, baik sedikit atau banyak menurut bagian yang telah ditetapkan". (QS. AlNisā' [4]: 7)

Kedua, kata نسَ berarti istri-istri sebagaimana ayat berikut:

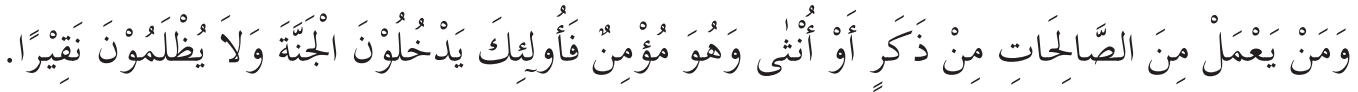

"Dan barang siapa mengerjakan amal kebajikan, baik laki-laki maupun perempuan sedang dia beriman, maka mereka itu akan masuk ke dalam surga dan mereka tidak dizalimi sedikit pun". (QS. Al-Nisā' [4]: 124)

Sesungguhnya bila kita cermati pemaparan di atas, semantik kata رَجُل mempunyai makna laki-laki maupun perempuan. Tidak demikian halnya

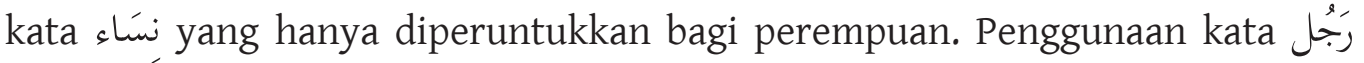
yang méncakup di dalamnya perempuan berdampak pada sikap berbahasa bahwasanya dominasi laki-laki terhadap perempuan sangat kuat.

Terlebihlagijikakata رَجُ seringkali dinisbatkan pada sosokyangberpengaruh seperti beberapa penafsiran ayat al-Qur'an, maka perempuan secara sadar atau tidak mengakui bahwa bahasa Arab dalam hal ini mengandung model patriarkis (mengistimewakan laki-laki). Bias makna tersebut mempengaruhi bentuk relasi sosial antara dua jenis kelamin dan pada akhirnya berubah menjadi hegemoni kekuasaan maskulin terhadap feminim yang berdampak pada lahirnya anomali sosial dalam masyarakat.

\section{Sرجّل Sifat yang melekat dengan kata}

Status semantik laki-laki dalam bahasa Arab (رجَجل) menurut Abu Hayyam kata رَجُج memiliki pengertian orang yang memiliki ketangguhan, yaitu tangguh dalam mengurusi dan menjalankan tanggung jawab. Orang yang tangguh adalah orang yang kuat. Masyarakat Arab sering mengatakan (Faisol, 2011: 97):

$$
\text { الرجل بين الرجولية والرجلة. }
$$

"Seorang laki-laki antara kejantanan dan kelelakian".

Atau dengan kata lain seorang laki-laki adalah sosok pemegang tanggung jawab atau pemimpin. Sebagaimana ayat berikut ini: 


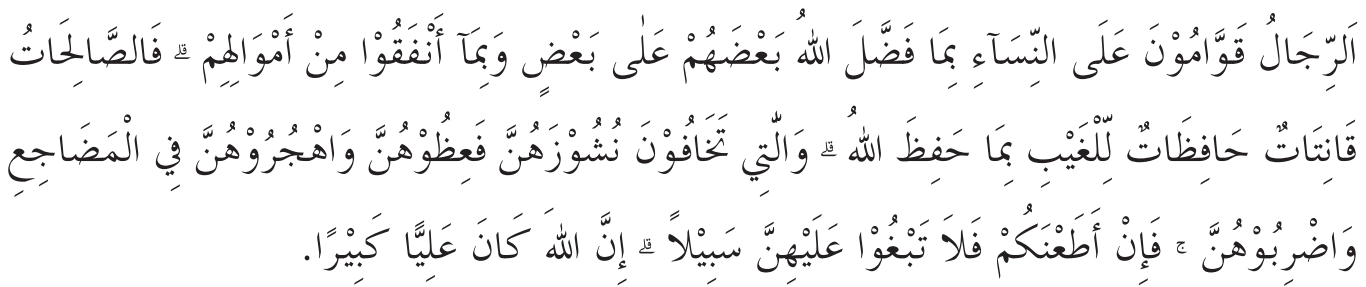

"Laki-laki (suami) itu pelindung bagi perempuan (istri), karena Allah telah melebihkan sebagian mereka (laki-laki) atas sebagian yang lain (perempuan), dan karena mereka (laki-laki) telah memberikan nafkah dari hartanya. Maka perempuan-perempuan yang saleh, adalah mereka yang taat (kepada Allah) dan menjaga diri ketika (suaminya) tidak ada, karena Allah telah menjaga (mereka). Perempuan-perempuan yang kamu khawatirkan akan nusyuz (meninggalkan kewajiban selaku istri, seperti meninggalkan rumah tanpa ijin suaminya), hendaklah kamu berinasihat kepada mereka, tinggalkanlah mereka di tempat tidur (pisah ranjang), dan (kalau perlu) pukullah mereka. Tetapi jika mereka menaatimu, makajanganlah kamu mencari-carialasan untukmenyusahkannya. Sungguh, Allah Mahatinggi, Mahabesar". (QS. Al-Nisā' [4]: 34)

Kata قََّّ yang berarti pelindung atau pemimpin melekat dengan kata . رَجُل Al-Qurtubi cenderung menafsirkan kata قَ'َّاّ dalam ayat di atas dengan melihat aktivitas laki-laki sebagai pencari nafkah, sementara Ibnu Abbas secara khusus menafsirkan kata kata قوَّ sebagai pihak yang memilki kekuasaan atau wewenang. Az-Zamakhsyari menjelaskan bahwa kata itu berarti laki-laki wajib ber-amar ma'ruf nahi munkar kepada perempuan, sebagaimana penguasa kepada rakyatnya. Superioritas laki-laki tersebut menurut Rasyid Rida, terjadi karena dua sebab, yaitu fitri dan kasbi. Sebab fitri terlihat bahwa lelaki lebih kuat, lebih tegap, dan sempurna. Sementara sebab kasbi terlihat bahwa laki-laki lebih mampu berusaha, berinovasi, dan bergerak. Oleh karena itu, lelaki dituntut untuk memberi nafkah kepada perempuan, menjaga, dan memimpinnya. Di pihak lain, perempuan diberi fitrah mengandung, melahirkan, menyusui, dan mendidik anak (DEPAG, 2009: 7).

Kata قَوَّمَ disebutkan dalam hadis Nabi Saw, sebagaimana berikut ini:

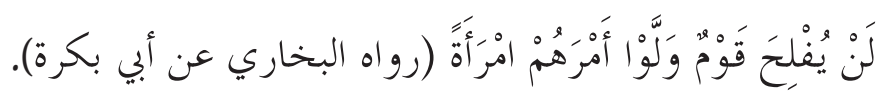

"Tidak akan berbahagia suatu kaum yang menyerahkan suatu urusan kepada perempuan". (HR. Al-Bukhāri dari Abū Bakrah)

Selain itu, kata laki-laki pada tradisi berbahasa masyarakat Arab mengandung makna sosok yang dominan serta menempatkan laki-.laki sebagai makhluk yang bermartabat, seperti puisi Arab berikut ini: 
أَبَوْكَ خَلْيْفَة وَلَدَتَهُ أُخْرَى

"Bapakmu adalah seorang khalifah yang dilahirkan oleh orang lain, dan engkau adalah seorang khalifah, Itulah kesempurnaan".

Khalifah dalam puisi di atas merujuk pada laki-laki, dalam tradisi budaya Arab tidak dijumpai khalifah perempuan baik pada zaman khalifah ar-rāsyidin, daulah Umayyah maupun daulah Abbasiyah.

Menurut Nasarudin Umar, kata disebut sebanyak 13 kali dalam al-Qur'an menunjukan arti wanita yang sudah dewasa sebagaimana lawan kata رَجُل مُ (Umar, 200: 71).

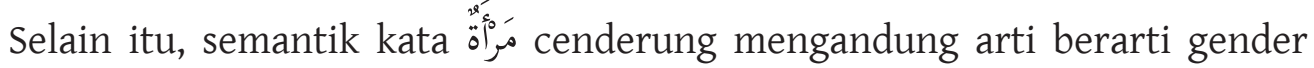
perempuan atau istri sebagaimana tradisi Arab menyatakan (Faisol, 2011: 95):

$$
\text { هذا قيام المرأة وقوامه. }
$$

"Orang itu (suami) yang mengurusi persoalan istri dan memberi perhatian dengan menjaganya".

Penafsiran semantik kata قَوَّام yang melekat pada kata رَجْام seperti tersebut di atas berimplikasi jauh, yakni perempuan tidak berhak menjadi pemimpin, bahkan mengatur hidupnya sendiri, ataupun meningkatkan kualitas dirinya sebagai hamba Allah SWT dan khalifah, apalagi memimpin orang lain.

Dengan demikian, laki-laki diidentikkan sebagai sosok superior yang memiliki potensi untuk menempati posisi strategis di ruang publik daripada perempuan yang dinilai tidak bisa mengembangkan karirnya dan lebih cocok kembali ke ruang domestik.

\section{Gelar yang diperuntukkan bagi laki-laki dan perempuan}

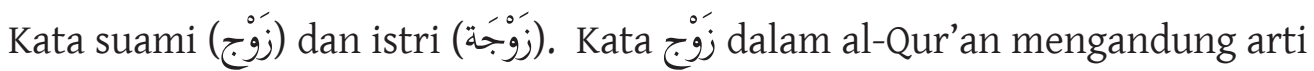
pasangan bagi setiap sesuatu, baik laki-laki maupun perempuan, hewan jantan dan betina atau bahkan makhluk-makhluk yang lain. Dalam al-Qur'an kata زَوْج terulang sebanyak 81 kali dengan berbagai bentuknya mengandung beberapa makna, di antaranya adalah:

Pertama, pasangan genetik jenis manusia, sebagaimana ayat berikut:

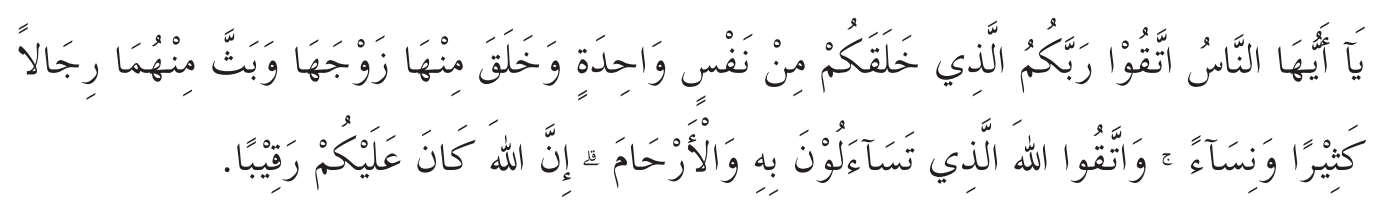

"Wahai manusia, bertakwalah kepada Tuhanmu yang telah menciptakan kamu dari diri 
yang satu (Adam), dan (Allah) menciptakan pasangannya (Hawa) dari (diri)nya; dan dari keduanya Allah memperkembangbiakkan laki-laki dan perempuan yang banyak. Bertakwalah kepada Allah yang dengan nama-Nya kamu saling meminta (menurut kebiasaan orang Arab, apabila mereka menanyakan sesuatu atau meminta kepada orang lain mereka mengucapkan nama Allah seperti as'aluka billāh artinya saya bertanya atau meminta kepadamu dengan nama Allah), dan (peliharalah) hubungan kekeluargaan. Sesungguhnya Allah selalu menjaga dan mengawasimu". (QS. Al-Nisa' [4]: 1).

Kedua, pasangan genetik dunia fauna, sebagaimana ayat berikut:

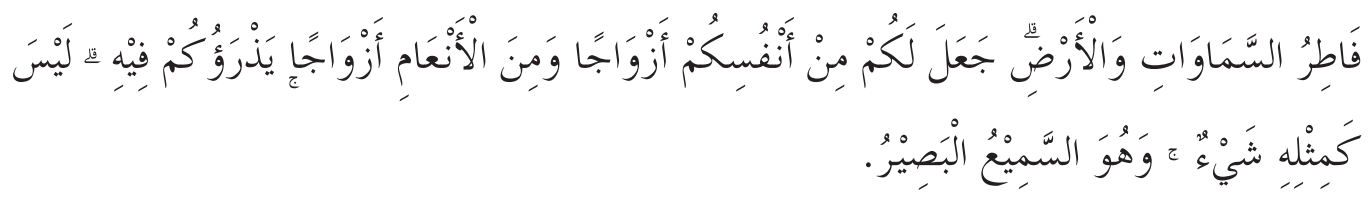

"(Allah) Pencipta langit dan bumi. Dia menjadikan bagi kamu pasangan-pasangan dari jenis kamu sendiri, dan dari jenis hewan ternak pasangan-pasangan (juga). DijadikanNya kamu berkembang biak dengan jalan itu. Tidak ada sesuatu pun yang serupa dengan Dia. Dan Dia Yang Maha Mendengar, Maha Melihat". (QS. Al-Syūrā [42]: 11)

Ketiga, bermakna istri, sebagaimana ayat berikut:

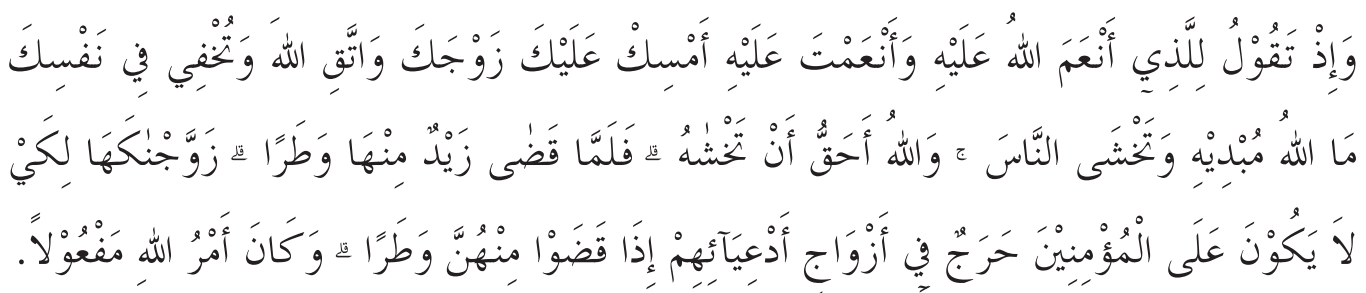
"Dan (ingatlah), ketika engkau (Muhammad) berkata kepada orang yang telah diberi nikmat oleh Allah dan engkau (juga) telah memberi nikmat kepadanya, "Pertahankanlah terus istrimu dan bertakwalah kepada Allah", sedang engkau menyembunyikan di dalam hatimu apa yang akan dinyatakan oleh Allah, dan engkau takut kepada manusia, padahal Allah lebih berhak engkau takuti. Maka, ketika Zaid telah mengakhiri keperluan terhadap istrinya (menceraikannya), Kami nikahkan engkau dengan dia (Zainab, setelah habis idahnya) agar tidak ada keberatan bagi orang mukmin untuk (menikahi) istri-istri anakanak angkat mereka, apabila anak-anak angkat itu telah menyelesaikan keperluannya terhadap istrinya. Dan ketetapan Allah itu pasti terjadi". (QS. Al-Ahzāb [33]: 37)

Keempat, pasangan bagi setiap sesuatu, sebagaimana ayat berikut:

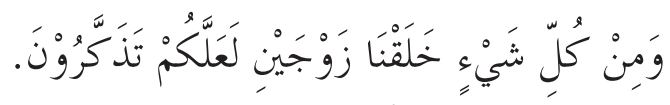

"Dan segala sesuatu Kami ciptakan berpasang-pasangan agar kamu mengingat 
(kebesaran Allah)". (QS. Al-Dzāriyāt [51]: 49)

Dalam al-Qur'an, kata زَوْج semua berbentuk mudzakar, menurut ahli nahwu khususnya dari Hijaz menganggap bahwa kata زَوْج mengandung makna mudzakar maupun mu'annats, sebagaimana ayat berikut (Mandzur, 1997: 70):

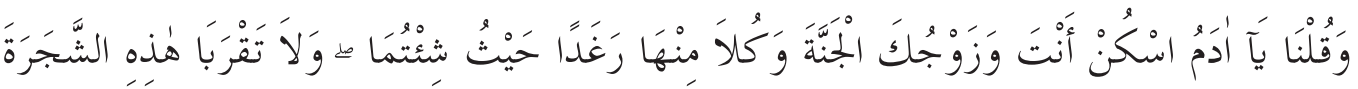

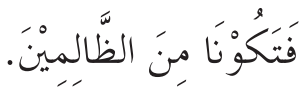

"Dan Kami berfirman, "Wahai Adam, tinggallah engkau dan istrimu di dalam surga dan makanlah dengan nikmat (berbagai makanan) yang ada di sana sesukamu. (Tetapi) janganlah kamu dekati pohon ini (menurut setan, siapa yang memakan buah pohon itu, akan kekal di dalam surga), nanti kamu termasuk orang-orang yang zalim". (QS. Al-Baqarah [2]: 35)

Dari uraian di atas, penggunaan kata زَوْْ زو dalam al-Qur'an semua berbentuk mudzakar atau dengan kata lain kata زو زو زو yang bermakna suami dalam bahasa Arab tidak memilki bentuk mu'annats. Namun fuqaha' nampaknya mengikuti pendapat Bani Tamim yang membedakan antara kata زَوَجَ yang bermakna suami dan kata زَوَجْ yang bermakna istri (Mandzur, 1997: 70).

Dengan demikian, pembentukan kata زَوْجَ jebenarnya merupakan bentuk turunan dari kata kata زَوَج yang terlebih dahulu ada. Sehingga secara tidak langsung perempuan tidak akan ada wujud konsistensinya sebelum laki-laki terlebih dahulu ada.

\section{E. Seksisme Bahasa Arab Tinjaun Sintaksis}

Berikut pemaparan mengenai bentuk seksisme dalam bahasa Arab ditinjau dari segi sintaksis.

\section{Penggunaan kata ganti (dhamir) untuk laki-laki dan perempuan}

Relasi gender dalam al-Qur'an terlihat dalam penggunaan dhamir (kata ganti) yang ditunjukkan untuk laki-laki dan perempuan. Sebagaimana yang digunakan dalam identitas gender, kata ganti laki-laki lebih mendominasi dalam alQur'an daripada kata ganti perempuan karena kaidah umum tata bahasa Arab menyatakan (Hazm, tanpa tahun: 324):

"Apabilah khitāb suatu nash digunakan dalam bentuk mudzakar, maka mu'annats termasuk di dalamnya selama tidak ada dalilyang mengecualikannya". 
Dalam konteks ini, menurut Jalaluddin al-Suyuthi, di dalam al-Qur'an perempuan kadang kala masuk ke dalam ujaran orang ketiga yang terdiri dari dua orang dengan satu lafal, seperti firman Allah SWT berikut ini (Suyuthi, tanpa tahun: 32-33):

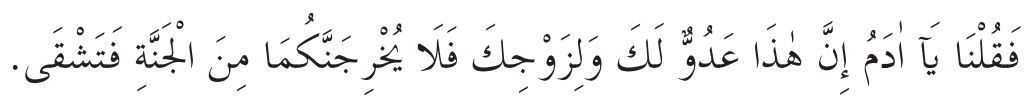

"Kemudian, Kami berfirman, "Wahai Adam, sungguh ini (Iblis) musuh bagimu dan bagi istrimu, maka sekali-kali jangan sampai dia mengeluarkan kamu berdua dari surga, nanti kamu celaka". (QS. Thāha [20]: 117)

Karena banyak ahli tafsir yang mengatakan bahwa yang mendapatkan beban tanggung jawab itu adalah Adam, dan pada saat yang lain nash tersebut juga mencakup Hawa. Akan tetapi, dia tidak disebutkan di dalamnya karena menurut sebagian ulama adalah justru untuk melindungi kehormatannya.

Sebagai kalām Allah yang berbahasa Arab, al-Qur'an juga mengikuti aturan ini, sebagaimana berikut:

"Wahai orang-orang yang beriman, diwajibkan atas kamu berpuasa sebagaimana diwajibkan atas orang-orang sebelum kamu agar kamu bertakwa". (QS. Al-Baqarah [2]:183)

Maskulinitas ayat tersebut terletak pada kata yang dicetak miring. Dalam ayat tersebut khitāb laki-laki mencakup juga perempuan, jika tidak maka ayat di atas tidak dapat dijadikan landasan kewajiban berpuasa bagi perempuan.

Namun hal ini tidak berlaku untuk sebaliknya, yakni jika khitāb untuk perempuan, maka ia dikhususkan pada perempuan saja, seperti ayat berikut:

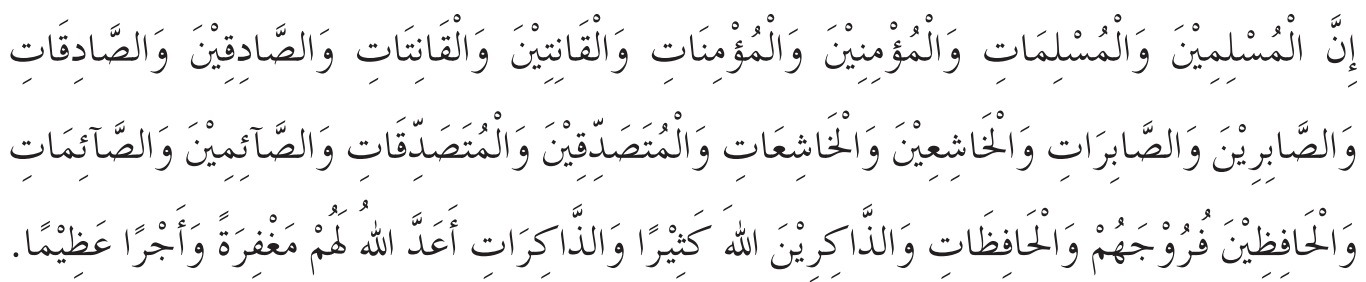
"Sungguh, laki-laki dan perempuan muslim, laki-laki dan perempuan mukmin, laki-laki dan perempuan yang tetap dalam ketaatannya, laki-laki dan perempuan yang benar, laki-laki dan perempuan yang sabar, laki-laki dan perempuan yang khusyuk, laki-laki dan perempuan yang bersedekah, laki-laki dan perempuan yang berpuasa, laki-laki dan perempuan yang memelihara kehormatannya, laki-laki dan perempuan yang banyak menyebut (nama) Allah, Allah telah menyediakan untuk mereka ampunan dan pahala yang besar". (QS. Al-Ahzāb [33]: 35) 
Menarik dicatat bahwa secara makna jamak mudzakar sālim hanya diperuntukan bagi yang berakal, sementara jamak muannats sālim meliputi yang berakal dan yang tidak berakal (Saqāl, 1996: 45).

Dengan pengertian lain, penggunaan makna jamak mudzakar sālim menunjukkan makna khusus bagi makhluk berakal, sedangkan jamak muannats sālim meliputi makhluk yang berakal atau tidak berakal seperti bentuk jamak

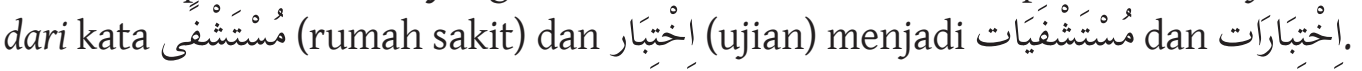

Sebagai bahasa al-Qur'an, seksisme bahasa Arab turut menjadi hal yang tidak bisa dipungkiri wujudnya dalam al-Qur'an. Sehingga Allah sebagai Dzat yang tidak berjenis kelamin pun mempunyai nama yang berjenis laki-laki yaitu mudzakar dan memakai kata kerja mudzakar (fi'il mudzakar). Sebagaimana ayat berikut ini:

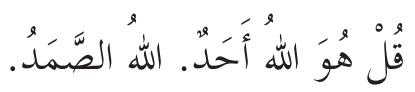

"Katakanlah (Muhammad), "Dia-lah Allah, Yang Maha Esa. Allah tempat meminta segala sesuatu". (QS. Al-Ikhlāsh [112]: 1-2)

\section{Penggunaan kata sifat (na'at) untuk laki-laki dan perempuan}

Sesungguhnya manusia, baik laki-laki maupun perempuan diciptakan oleh Allah sesuai kodratnya, sebagaimana ayat berikut:

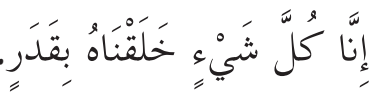

"Sungguh, Kami menciptakan segala sesuatu menurut ukuran". (QS. Al-Qamar [54]: 49)

Kata “قَ" menurut Quraish Shihab berarti ukuran sifat-sifat yang ditetapkan Allah SWT dalam segala sesuatu. Atau dengan pengertian lain laki-laki atau perempuan sebagai individu dan jenis kelamin memiliki kodratnya masingmasing (Umar, 2001: xxix).

Sehubungan dengan penjelasan kata قَوَّام yang melekat pada kata رَجُل pada surat Al-Nisā' [4]: 34. Menurut Rasyid Rida, superioritas laki-laki terjadi karena dua sebab, yaitu fitri dan kasbi. Sebab fitri terlihat bahwa lelaki lebih kuat, lebih tegap, dan sempurna. Sementara sebab kasbi terlihat bahwa laki-laki lebih mampu berusaha, berinovasi, dan bergerak. Oleh karena itu, lelaki dituntut untuk memberi nafkah kepada perempuan, menjaga, dan memimpinnya. Di pihak lain, perempuan diberi fitrah mengandung, melahirkan, menyusui, dan mendidik anak. Sehubungan dengan fitrah laki-laki dan perempuan bisa dilihat dari penyataan Quraish Shihab berikut ini (Shihab, 2000: 156): 
"Kekuatan laki-laki dibutuhkan oleh wanita, dan kelemahlembutan wanita didambakan oleh laki-laki”.

Atau dengan pengertian lain, fitrah laki-laki adalah kesempurnaan, kekuatan dan kepemimpinan (male dominated), sebaliknya perempuan sosok lemah yang ditempatkan di posisi marginal.

\section{F. Seksisme Bahasa Arab Tinjaun Morfologi}

Berikut pemaparan mengenai bentuk seksisme dalam bahasa Arab ditinjau dari segi morfologi.

1. Proses pembentukan kata benda perempuan

Menurut Dīzirah Saqāl, dalam bahasa Arab bentuk kata laki-laki (mudzakar) merupakan dasar pembentukan kata perempuan (muannats), oleh karenanya laki-laki harus lebih diutamakan daripada perempuan karena bentuk kata perempuan dalam bahasa Arab dibentuk dari laki-laki (Saqāl, 1996: 145).

Dalam konteks ini, senada dengan pendapat Dīzirah Saqāl, Ibnu Anbari menyatakan sebagaimana berikut (Anbari, 1970: 63):

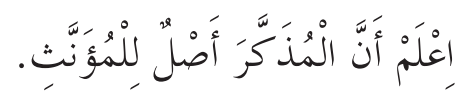

"Ketahuilah bahwa bentuk kata laki-laki (mudzakar) merupakan dasar pembentukan kata perempuan (muannats)".

Sebagai contoh, kata بْبَ berasal dari bahasa Arab yang akar katanya adalah

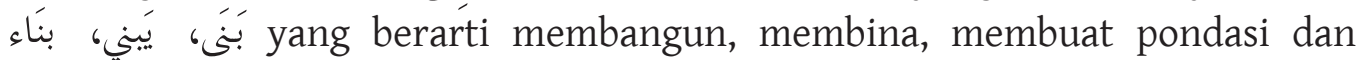
mémbúat sesuatu yang baru. Kata ابَنَّنَ menurut al-Asfahani berasal dari kata Kemudian wawu diganti dengan hamzah washal yang diletakkan di awal kata ini

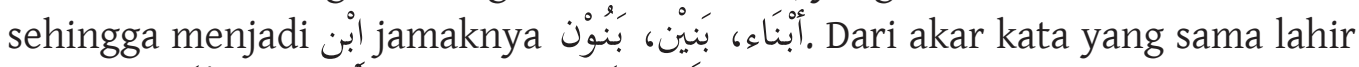

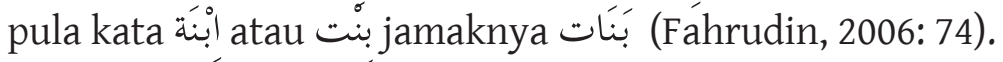

Dalam bahasa Arab, banyak ditemukan bentuk kata perempuan (muannats) yang dibentuk dari laki-laki (mudzakar), di antaranya sebagai berikut:

Pertama, Muslim laki-laki (مُمْلم) dan Muslim perempuan (مُمْنمَمة).

Bentuk morfologi kata Muslim laki-laki (مُسْمَم) berasal dari akar kata:

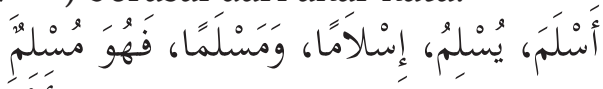

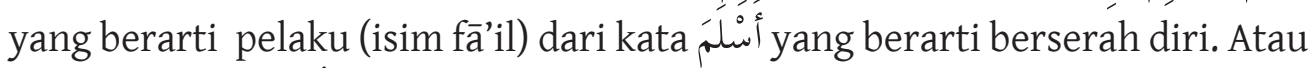
dengan kata lain مُسْ berarti orang yang berserah diri (kepada Allah). Dari akar kata yang sama lahir pula kata Muslim perempuan (مُسْمَمَّمَ). 


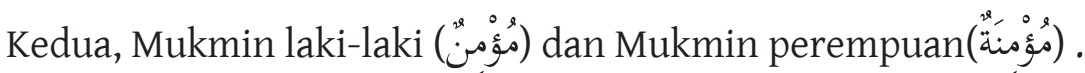

Bentuk morfologi kata Mukmin laki-laki (مُوْْنَ berasal dari akar kata:

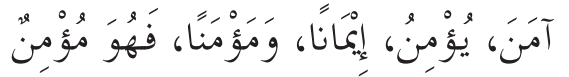

yang berarti pelaku (isim fä’il) dari kata آََّ' yang berarti yakin. Atau dengan

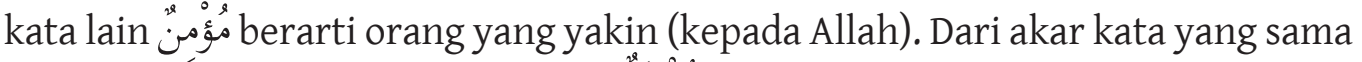

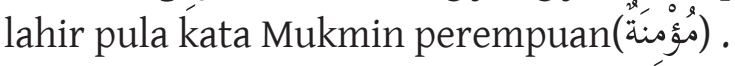

Dalam konteks ini, terdapat pelecehan linguistik-metodologis yang sengaja mempersempit ruang gerak perempuan dengan cara menciptakan bahasa turunan dari laki-laki. Sufiks tă' marbūthah (identitas muannats) pada kata

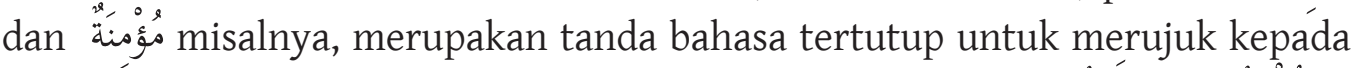
perempuan. Kata- kata tersebut merupakan turunan dari kata طُؤْمِنْ

\section{G. Seksisme Bahasa Arab dan Tantangan Pembelajaran Bahasa Arab}

Seksisme dan pendidikan menarik untuk dihubungkan karena beberapa alasan. Pertama, lembaga pendidikan adalah wadah institusional di mana semua pegawai, baik laki-laki maupun perempuan, mengekspresikan segala potensinya, mengaktualisasikan dan mendefinisikan identitas dirinya. Kedua, lembaga pendidikan merupakan institusi dinamis yang menyiapkan, memproduksi, dan mengembangkan sumber daya manusia. Ketiga, lembaga pendidikan mereproduksi ideologi atau doktrin tertentu, baik melalui proses kebijakan atau melalui proses inkulturasi atmosfer kerja. Melalui proses pendidikan, nilai-nilai diperkenalkan, ditransmisi, dan ditransformasikan. Sebagai implikasi lebih lanjutnya, maka proses pembelajaran dan lembaga pendidikan memiliki peranan signifikan untuk mengkonstruksi ketimpangan atau kesetaraan gender.

Sebagai bahasa yang memiliki perbedaan gender yang cukup ketat, fenomena seksisme bahasa Arab tidak terelakkan lagi. Menarik dicatat bahwa faktor intern sistem bahasa Arab seperti semantik, sintaksis, morfologi, dan penafsiran wacana perempuan dalam al-Qur'an dan hadis turut memberikan corak tersendiri dalam fenomena seksisme bahasa Arab.

Dalam konteks seksisme bahasa Arab dan tantangan pembelajaran bahasa Arab terdapat pelecehan linguistik-metodologis yang sengaja mempersempit ruang gerak perempuan dengan cara menciptakan bahasa turunan dari lakilaki. Dan pada akhirnya, perempuan hanya mendapatkan bagian dari sisa-sisa 
kekuasaan subordinasi mereka. Melalui sifatnya yang seksis, bahasa Arab secara tidak langsung terus mempengaruhi pemakai bahasanya dalam cara pandang, berpikir dan bersikap secara turun menurun.

Pendidikan merupakan hak setiap orang, baik laki-laki maupun perempuan. Oleh karena itu, sudah seharusnya tidak ada alasan untuk mendiskriminasikan pendidikan perempuan. Namun sayangnya, fenomena yang sering kita jumpai dalam proses pendidikan masih bersifat patriarkhis. Tidak sedikit dijumpai materi-materi pendidikan yang seksis yang bersumber dari rentetan pertentangan gender yang bergemuruh dalam masyarakat. Sementara pendidikan di sisi lain menjustifikasinya sebagai suatu kebenaran etika.

Pola pengkerdilan perempuan dalam dunia pendidikan lewat teks pelajaran merupakan manifestasi stereotip yang bisa dilihat sebagai bagian dari bentuk stereotip perempuan dalam berbagai wacana keagaaman yang bersumber dari penafsiran dan pemahaman al-Qur'an dan hadis.

Kalimat-kalimat maupun deskripsi kalimat dalam buku pelajaran yang mengadung seksisme bahasa Arab sebagaimana dicontohkan di atas sebenarnya adalah pintu awal untuk menanamkan pembelajaran yang berbias gender yang lebih parah dan sistemik kepada peserta didik. Dengan kata lain, kurikulum yang memuat bahan ajar bagi siswa belum bernuansa netral gender karena kentalnya bahasa seksis dalam ilustrasi kalimat yang dipakai dalam penjelasan materi.

Bahasa patriarkal yang menjadi penyebab utama tumbuhnya ketidakadilan gender, terutama dalam dunia pendidikan sebenarnya harus dilawan dengan usaha memasyarakatkan bahasa yang ramah gender. Artinya, jika seksisme bahasa Arab menjadi sindroma akut tiadanya kesetaraan gender dalam ranah pendidikan terutama pendidikan agama, maka bahasa pula yang harus dijadikan sandaran teoritis untuk menaklukan ketidakadilan tersebut. Hal ini disadari karena bahasa merupakan realitas konkrit yang tidak bisa dilepaskan dalam kehidupan umat manusia secara umum.

Pengaruh dari sosialisasi peran gender yang timpang melalui seksisme bahasa dalam teks pelajaran maupun lewat proses pembelajaran, dapat berimplikasi negatif dengan mempersempit pilihan-pilihan masa depan perempuan. Seksisme bahasa dalam pendidikan semakin mengkerdilkan perempuan dari ketimpangan sistem patriarkal, sehingga perempuan tetap menjadi the second sex di bawah bayang-bayang laki-laki.

Satu aspek penting yang tidak bisa dikesampingkan jika ingin membangun 